\title{
Children's Protection in the Issue of Hadhanah Based on Islamic Family Law and The Law of Thailand
}

\author{
Rohanee Machae (Corresponding author) \\ Department of Syariah, Faculty of Islamic Studies, \\ National University of Malaysia. \\ Tel: +6017-4516764 E-mail: nee_2750@hotmail.com,
}

\author{
Abdul Basir Mohamad \\ Comparative Tort Law, Islamic Criminal Law and Islamic Studies \\ Department of Syariah, Faculty of Islamic Studies, National University of Malaysia. \\ Tel: +603 89215940 E-mail: abasir@ukm.edu.my \\ Mutsalim Khareng \\ Department of Theology and Philosophy, Faculty of Islamic Studies, \\ National University of Malaysia. \\ Tel: +6012-2678209 E-mail: habba_yabnee@hotmail.com,
}

\begin{abstract}
This paper analyses Children Protection in the Islamic Family Law of Southern Thailand and the Civil Law of Thailand. The common issue faced by the Court or the District Islamic Department is the rising number of hadhanah claim cases. This research is meant to investigate the rights of children regarding hadhanah based on the Islamic Family Law of Southern Thailand and to what extent the laws follow the principles of Islamic law. This research utilized few approaches which are the content, deductive, inductive, and comparative analysis. Basically, the findings suggest that the differences between the two laws can be accepted as both laws originated from distinguished backgrounds. Therefore, both laws play crucial roles in completely protecting the children in hadhanah cases, as well as promising safety and peaceful life for the children even though their parents' relationship is in crisis.
\end{abstract}

Keywords: Children, Protection, Hadhanah, Islamic Family Law, Civil Law of Thailand.

\section{Introduction}

Hadhanah, or child custody, is one of the classic issues that occur as a result of parental divorce.

In the era of Rasulullah (PBUH), there was a debate among the companions on who has the utmost right for child custody after a divorce. Presently, the issue of hadhanah is still occurring when the parents divorced and each of them claim the right of child custody without taking into consideration their children's needs and wants, especially the children who have reached their puberty and mumayyiz. Children will always suffer the after effect of parental divorce as they will lose the love, attention and happiness, as well as, face some psychological issues, including the issue of child custody. The fighting of child's custody among the parents will add to children's psychological burden. This is unfair to them as children are the most valuable gift given by Allah. Therefore, a divorce cannot deny the children's ultimate rights as mentioned by the shariah law. Parents should take good care of the gift given to them by fulfilling their children's rights. Among the rights of children that should be fulfilled by the parents are; rights for love and attention, rights for alimony, rights to live with the parents or rights for education and safe life guarantee 
(Ibrahim. 2006).

\section{Research Background and Problem Statement}

Child custody is not an alienated issue among parents who got divorced in many countries including Thailand. The common issue that emerges after a divorce of a couple who has children is undeniably the issue of child custody. If the divorced couple fails to decide who should get the child's custody, the case will be brought to the Court and the Islamic Department according to Office of Juvenile Justice System Development, Department of Juvenile Observation and Protection 2013. As a result, child custody cases always increase if compared to other cases registered in court statistics. This is also due to parents' responsibility in promising a safety and better life for their children.

Other than that, power abuse in treating the children could also endanger the parents, children and society. This might be caused by the serious social issues such as cold relationship between children and parents. That kind of relationship could also be the result of parents' treatment towards their children since they were young. In brief, the cases of abuse, rape and child abandonment are common in today's society (Mohd Zin et al., 2007). Thus, a complete law constitution is needed in protecting the children and their future.

In reference to that issue, the researcher believes that it is very suitable to conduct a study on it, in order to investigate and understand the protection and responsibilities that should be fulfilled by Muslim parents towards their children. The study focues on the Islamic Family Law of Southern Thailand which is related to the hadhanah rights as well as children protection as determined by the Shariah law. The following explanation will highlight on few cases that have been put on court trial in analysing the court's decision in determining the conditions for a person to get the hadhanah rights. For that reason, the researcher will briefly explain the history of law of Thailand as an introduction.

Thailand is known as a multi-religious country, as the constitutions considerate the differences, especially the existence of Islamic Family Law that is applied by only the Muslims. There are two types of law that are implemented in Thailand as its basic law. The two laws are the Civil Code and Trade Chapter 5 and 6 and the Islamic Family Law of Southern Thailand. The Islamic laws of Southern Thailand are only applicable to the Muslims in the 4 districts of South Thailand, namely, Pattani, Narathiwat, Yala and Satul. However, the Civil Code is applicable to all citizens of Thailand, including the Muslims who are not living in the 4 specific districts mentioned (The Islamic Family Law of Southern Thailand: 2011). Consequently, this study will be discussed based on the two laws implemented in Thailand: the Civil Code of Thailand and the Islamic Family Law of Southern Thailand, in investigating the level of child protection in the issue of hadhanah. This study uses the qualitative approach that includes content, deductive, and inductive analyses, as well as the comparative method.

\section{Children Protection in Hadhanah According to the Law}

\section{Hadhanah According to the Islamic Family Law}

When a divorce happens, the child's custody will be held by the husband since a father possessess the ultimate right towards his children. This is because, he is responsible for the children's maintenance or alimony. Nevertheless, a divorced woman is also entitled to hold the child's custody based on a few terms and conditions. According to Salleh (1992) Hadhanah can literally be defined as taking care and nurturing the young children by providing maintenance and education. It can also be defined as holding the children and educating them since they were born. Hadhanah is derived from the Arabic root word al-Hidn which means 
ribs or chest. Based on the meaning of the word, it is connected to the nurturing act, as usually the mother or the nanny will tightly hold the child close to their ribs or laps.

Other than that, according to the syarak term, hadhanah can be defined as the act of educating or nurturing the children by anyone who has been given the hadhanah rights by the syarak. It is also defined as nurturing and taking care of people who are not able to take care of themselves from things that could hurt them as they cannot differentiate between good and bad things (not mumayyiz) such as children, people who are insane and the disabled. Hadhanah also comprises the act of providing the children's needs, such as, food, drink, clothes, health, education and other necessities (al-Zuhayli. 1985).

Most of the fiqh scholars including Sabiq (1967) agreed that hadhanah is compulsory in nurturing and taking care of the young children. This means, by neglecting the responsibility, the children will be exposed to danger and destruction. The wisdom behind the obligation of hadhanah is to maintain the responsibility related to nurturing and providing education to young children. This is due to the possibilities of the divorced parents neglecting their responsibilities in educating and nurturing their children. If that happens, the children will be the victims who do not have the opportunity to enjoy their rights. The possibilities of having their future wheel is always there. Thus, this law is important to determine the eligible party to take care and nurture the children. It cannot be denied that hadhanah is the young children's rights as they are still in need of the adults to take care of them and manage their educational matters. Therefore, a mother is responsible to perform hadhanah (al-Asiliy. 2010). According to the hadith by Rasulullah, "You (the mother) are the most eligible to take care of the children". By referring to the hadith, mothers have been said to hold the rights to nurture and care for the children. Islam prioritises women to hold the hadhanah rights as women naturally have strong instinct and love towards the children as well as patience in educating and nurturing the children compared to man (Abdul Malek. 2007).

Nonetheless, if the mother has passed away or the mother who is still alive refuses to take care of her children, the child's custody will be the responsibility of the grandmother. In addition to that, it is a lot better if the child's custody is given to the grandmother on the mother's side. This is because; a grandmother has the woman instinct that could be applied in loving and nurturing the children. If the grandmother of the mother's side could not take the responsibility of the child's custody, the rights would go to the grandmother on the father's side. Besides, if the grandmother of the father's side could not take the child's custody, the mother of the grandmother should take the responsibility. The priority of who should hold the child's custody is arranged as follows; sisters of the same parents, sisters of the same mother, aunts of the mother's side, aunts of the father's side, daughters of the brothers and lastly daughters of the sister (al-Nawawi. n.d.).

As mentioned earlier, women have the ultimate rights in child's custody rather than men as they are more capable of loving the children. Howerer, if the children do not have any female relative, or they refused to take responsibility, the child's custody goes over to the men. In this case, the children's mahram by following the arrangement of the wealth inheritors with the exception for the grandfather since a grandfather is prioritised more than other male relatives. The inheritors' priority is arranged as follows; father, grandfather and great grandfather, brothers of the same parents, brothers of the same father, nephews of the same parents, nephews of the same father and the next inheritors (al-Dusyuqi. n.d.).

The immediate relatives are given the priority in holding the child's custody as they are believed to love the children more than the other relatives. Therefore, if the male or female relatives fight for the child's custody, the priority of the rights 
is arranged as follows; mother, grandmother of the mother's side or the great grandmother of the mother's side, father, grandmother of the father's side, grandfather of the sisters (same parents) from the father's side and the next following inheritors (al-Syawkani, n.d.). Furthermore, the terms and conditions to get the hadhanah rights are listed as follows; a.)Sane, b.) Muslim, c.)Honest and possess good attitude, d.) Possess a permanent place for living, e.) The mother does not involve in a new marriage (Mustafa al-Khin. 2009).

Other than the terms and conditions that should be fulfilled by the guardian, the period of child's custody based on the syarak should also be highlighted. The period of child's custody based on the syarak is until the children know how to differentiate between good and bad (mumayyiz). In Mazhab al-Syafii, the period of child's custody will end once the child reaches his or her mumayyiz state, which is at the age of 7 years old. That means, once the child reaches 7 years old and declared as mumayyiz, he or she is given the option whether to live with his or her mother or father (Mustafa al-Khin, M.B. 2009). From that statement, the rights for child's custody belongs to the chosen person made by the children themselves. This is supported by the hadith of Rasulullah (PBUH) which means "Prophet Muhammad (PBUH) gave freedom for a child whether to follow his father or his mother" (al-Mubarakfuri. n.d.).

If the mumayyiz child chose his father, but the father is not eligible to be the guardian, or the father is missing, the responsibility will go his grandfather, based on the arrangement that has been mentioned earlier. If the child is a girl who is reaching her puberty, the child's custody should not be given to her cousin of her father's side. However, if that cousin is the only person who can be the guardian, he has to find a trusted woman to nurture that girl with his assistance.

In short, the choice made a mumayyiz child in living with whom he or she prefer is valid until that child reaches his or her puberty or get married. If the mother who carries the hadhanah responsibility reaches her 'iddah period, she is entitled for some payment of nurturing her child. The payment mentioned is related to the payment for nursing the child, since a mother is not entitled for any payment if she is still a wife or in her 'iddah period. This because, in the period of being a wife or 'iddah, the woman is still entitled for the family or 'iddah maintenance from her husband (Qasim. 1992). The statement is clearly supported by the words of Allah in surah al-Baqarah verse 233 and surah al-Thalaq verse 6 . Conversely, if the woman who is nurturing the child is a stranger, who is not the biological mother of the child, she is entitled for the payment starting from the first day she nurtures the child. In other words, it is compulsory for the father to make payment to the woman who nurtures his child except his wife. Furthermore, if the woman who is nurturing his child does not have a place to live, the father is responsible to provide the shelter for her and the child (Aqlah. 1990).

\section{The Law of Hadhanah According to the Islamic Family Law of Southern Thailand}

According to the Islamic Family Law of Southern Thailand, there are two different definitions of the two terms which are custody rights and nurturing rights. The provisions of clause 319 defines that custody is the rights for power in taking care of the children in ensuring their good life, as well as managing all matters related to the children such as their properties, being their representatives, protecting them from destruction and other related matters. Meanwhile, rights of nurturing are defined as rights in raising, taking care and educate the children. In addition, the rights are also focusing on loving and providing good things to the children especially protecting them from danger (Islamic Family Law of Southern Thailand clause 329).

However, the implementations of both terms are defined in different ways. Custody rights 
are prioritised to the father, followed by the grandfather and the next following successors. This means, father is the responsible party in taking care of all matters related to the children. If the children have lost their father, the responsibility will be transmitted to the grandfather. Nevertheless, if the grandfather and the next successors are also absent, a person who is appointed by their father or their grandfather will be the guardian and he or she will have the power in managing all matters related to the children.

On the other hand, if there is nobody appointed by the father or the grandfather of the children, the Judge from the district has to appoint someone to be the children's guardian (Case in Narathiwat Court Civil Case No. 1322/2551). This is because, the qualifications in nurturing the children are extremely vital as they are determined by the syarak and Islamic Family Law of Southern Thailand as explained in the provisions clause 322 which highlights the most important condition for a guardian is he or she must be a Muslim. This is vital if the guardian is non- Muslim, the children will be at risk of hearing slanders about Islam from their guardian.

Basically, rights of hadhanah principally belongs to the mother, as mentioned in the provisions clause 335 which states mother is the first eligible person in nurturing the children (Ibid, 335). Nonetheless, if the mother is nonMuslim, the objective of hadhanah is not accomplished. In brief, Islam will only give the rights of hadhanah to an individual who fulfils all the conditions listed especially being a Muslim (al-Syatibi, 1997).

It can be summarised that rights of nurturing is different from rights of custody. This is because, the provision in clause 334 states that the conditions to be the caretaker of the children must not necessarily be Muslim, but he or she should only be sane, honest, volunteer, not hypocrite and love children. By referring to the above statement, being Muslim is not stated as among the conditions to be the children guardian. This provision puts the syarak and the Islamic Family Law of the Southern of Thailand in conflict with each other. Even though the provision clause 334 did not clearly list being Muslim as the condition to be a guardian, the second paragraph mentions that if the guardian slanders the children's religion and faith, that person's right to be a guardian will be denied. This is because, that person has caused destruction to the children's life. In short, by putting the condition for the guardian to be Muslim, the risk of children's faith from being destructed can be avoided as they will be raised according to the principles of Islam.

In the case of Daud Derae; no. Y.J 14/2552, the High Court decided to accept his hadhanah claim to be his child's guardian. Since the child is a Muslim and lives in Narathiwat, the case trial was referred to the Islamic Family Law of Southern Thailand. The statement in this claim parallels the provisions clause 322 which listed the main condition to be the guardian is being Muslim. This is vital due to the need of preserving the children's religion and faith from slander.

The other condition to hold the child's custody and nurturing rights discussed by the scholars is honesty. This is highly significant as it is related to the condition of being Muslim. According to the Imams of the four mazhab, an eligible person should be honest in his or her religion. The definition of honesty in religion is discipline and does not take an advantage by doing negative things to the children. This condition is listed to preserve the children's welfare (Muda. 2009). In other words, if the nurturing rights of the Muslim children are given to the non-Muslim, the question of whether he or she will allow someone with or without honesty to be the guardian of the children should be taken into consideration.

The previous statement suggested two different conditions to the researcher. This is because; a non-Muslim is not necessarily dishonest. If 
the non-Muslim guardian nurtures the Muslim children sincerely, and he or she does not perform anything that could harm the children, that guardian has the rights to continue with the hadhanah. The non-Muslim is distinguished by his or her faith, but a dishonest person could harm others. Therefore, in the case of two persons who are fighting for the child's custody where one of them is Muslim but dishonest, compared to the other person who is non-Muslim but honest, the researcher thinks that the non-Muslim but honest person is more entitled to get the child's custody.

Other than that, the priority to hold the child's custody and nurturing rights are different in the arrangement of this provision. In the provision clause 321 , father, grandfather and great grandfather are the first rightful person to be the guardian, or the person appointed by the father or the grandfather. Nevertheless, in the provision clause 335 , the priority is given to the mother, daughter, grandmother or great grandmother of the mother's side, followed by the father and other successors to nurture the children.

In reference to the above statement, it can be seen that the priority for child's custody and rights of nurturing are different. In the provision clause 321 , father and grandfather are the main parties regarding the child's custody. The following parties would be the people appointed by the father or the grandfather who have agreed to be the guardian. This is because; the provision explains the statement by relating the child to the father through the valid marriage akad as mentioned in the Hadith of Rasulullah (PBUH); from Shuaib, from his grandfather Abdullah bin Amru; Rasulullah (PBUH) said that; "A child who lost his or her father, that child is connected to the father, therefore the successors should connect the child to the father" (al-Azdi. n.d.).

Conversely, in the provision clause 335, rights of nurturing the children belongs to the mother. If the mother is absent, the rights will be transmitted to daughter, followed by the grandmother on the mother's side. However, if the first two female relatives mentioned before are absent, the father and the successors on the father's side should hold the rights. If they still could not find the guardian, the rights should go to the elder or younger sister. This means, if there is no daughter or grandmother of the mother's side, the child will be transmitted to the father's successors permanently. This explanation is different from the other laws such as Brunei Family Law (PDUUKIB), Jordan Family Law, Kuwait Family Law and Wilayah Persekutuan Family Law 2006.

Based on the Brunei Family Law (PDUUKIB) provision clause 188 , mother is the most rightful person to be the children's guardian. If the mother is not eligible to be the guardian based on syarak, the rights will be transmitted to the grandmother or great grandmother of the mother's side. On the other hand, if the guardian mentioned in clause 188 is not present, the child's custody will be given to the male side which are father, grandfather and great grandfather, male siblings, uncle and the rest will follow the arrangement for marriage wali (Brunei Family Law 1999).

In the Jordan Family Law provision clause 154, the biological mother is the most rightful person to nurture and educate the children when she is still in the marriage and after divorce. After the mother, the rights will be handed to the female party by following the arrangement provided by Mazhab Hanafi (Mulhim. 1998).

The Kuwait Family Law explains this issue in clause 189 which stated the hadhanah rights belongs to the mother, followed by the grandmother or great grandmother of the mother's side, female siblings of the same parents, mother's aunt, father's aunt, grandmother of the father's side, father and the next successors 189 (Qanun Ahwal alSakhsyiyyah. 1984).

By referring to the Islamic Family Law of Wilayah Persekutuan (1984), clause 81 proves 
that mother is the most rightful person to hold the child's custody. However, if the court decides that the mother is not eligible to be the guardian based on syarak, the rights will be transmitted to the grandmother of the mother's side, followed by the father, grandmother or great grandmother of the father's side.

The provision for the arrangement of the hadhanah rights after the mother in the four laws mentioned earlier are different from the arrangement in the Islamic Family Law of Southern Thailand clause 335. The difference emerges as each law follows certain mazhab out of four accredited mazhab. This can be seen as Jordan Family Law follows Mazhab Hanafi, Kuwait Family Law follows Mazhab Maliki, while Islamic Family Law of Wilayah Persekutuan and Brunei Family Law follow Mazhab Syafie.

Even though the Islamic Family Law of Southern of Thailand also follows Mazhab Syafie, it is different from the Islamic Family Law of Wilayah Persekutuan and Brunei Family Law in terms of the arrangement of priority on who should hold the child's custody after the mother. The Islamic Family Law of Southern Thailand gives priority to the daughter if the mother is not eligible to be the guardian or gone missing, while the other two laws give the rights to the grandmother or great grandmother of the mother's side to hold the responsibility. Besides, the decision will also be made by the Judge of the Islamic Family Law of Southern of Thailand by depending on the certain situations and relevance. Consequently, if the child is a girl who has not reached her puberty, relevance should be the main concern to be taken into consideration for any decision.

Other than that, if the mother is not eligible to be the guardian while the child does not have other successors who are eligible, the authority can file an application to appoint any party who is eligible to be the guardian based on the clause 322 , as explained in the provision clauses 321 and 327. For instance; in the case no. 278/2549 in Pattani, the court decided to give the child's custody of five children to their aunt of their mother's side since they are not under anyone's custody (Civil Case of Pattani Court no. 278/2549).

The next situation is for the children who have reached their mumayyiz state, the court will make the decision of child's custody based on what has been chosen by the children themselves, either to live with their mother or father. This guide is in the Islamic Family Law of Southern of Thailand clause 337. In accordance to the Islamic Law provision clause 1(13), mumayyiz can be defined as children or teenagers who can differentiate between positive and negative matters.

Normally, children reach their mumayyiz state at the age of 7 and half years old. That means, when they have reached that age, they have the right to choose whether to live with their father or mother. However, if the chosen party is not eligible to hold the responsibility, the rights will automatically be handed over to the other party. In contrast, if the party who is not eligible before has fulfilled the conditions of the eligibility, a new choice can be made by the children. Other than that, if the father holds the child's custody over a son, he cannot prohibit the son from meeting his mother. Conversely, if the father holds the child's custody over a daughter, he can prohibit the daughter from meeting her mother, but he cannot prohibit the mother from meeting her daughter. Overall, if the father who holds the child's custody over a son or a daughter when he is sick, the mother has the rights to take her children to live with her. In proportion to clause 337, if the children chose to live with both of their parents, a voting system will be utilised to determine who is the most rightful person to get the child's custody. In contrast, if the children did not make any decision, the rights will automatically go to the mother as mentioned in clause 338. Besides, if the parents live far from each other, the decision of which party the children should live with must be made according to the benefits that they 
will enjoy at present and in the future as listed in clause 339 . Other than that, the responsibility of providing the education for the children lies under the custodian, but not under the caretaker. For example, if the mother is the caretaker of the children, she is not responsible to provide the suitable and comprehensive education for them, as the responsibility should be carried out by the father.

Nonetheless, the Islamic Family Law of Southern Thailand keeps on protecting the safety and peaceful life of the children. This is proven as the mother who holds the hadhanah is protected to ensure that the children are perfectly nurtured. In addition, love between the mother and the children can be preserved even though their parents' marriage has ended. In short, mother is the most rightful person to get the rights of hadhanah compared to the others (Ibid, 335).

\section{Hadhanah According to the Civil Law of Thailand}

The explanation of hadhanah in the Civil Law of Thailand is different from the Islamic Family Law of Southern Thailand especially in relation to the child out of wedlock. In the Civil Law of Thailand, the definition of legitimate child is the child who was born out of parents who registered their marriage under the Civil Law or under the legitimate child registration performed by the father or under the court's decision in acknowledging the legitimate child.

As a result, if the child has any one of the conditions mentioned earlier, he or she is acknowledged as the legitimate child under the Civil Law of Thailand clause 1547. However, of the parents did not register their marriage, but the father wants to be the guardian of that child, he can register him or her as a legitimate child under the law as long as the mother and the child agreed for the application. This issue is mentioned in the Civil Law of Thailand clause 1548 which stated that a father can register his child as a legitimate child with the agreement from the mother and the child. If the mother and the child disagree or did not give any decision, they will be given 60 days to if they are living in Thailand, and 180 days if they are living abroad to make the decision. If they disagree for the application as they do not like the father, the case can be referred for court decision.

Meanwhile, the definition of legitimate child in the Islamic Family Law of Southern Thailand is a child who was born out of married parents according to syarak or the Islamic Family Law of Southern Thailand. Thus, there are differences between the marriage registrations in the Islamic Family Law of Southern Thailand and the Civil Law of Thailand. In compliance to the Civil Law of Thailand, parents who did not register their marriage will produce child out of wedlock. Therefore, if there is any claim for hadhanah towards that child, it cannot be continued. This is because, if the child was born out of unregistered marriage, he or she will automatically belong to the mother. This has caused problems in the implementation of the law in Thailand especially among the society in the Southern Thailand. The Islamic Family Law of Southern Thailand stresses that if the marriage is legal according to syarak, the child who was born out of that marriage is legitimate. Nonetheless, in the Civil Law of Thailand, if the child was born out of unregistered marriage; he or she is a child out of wedlock.

Essentially, the society in the Southern of Thailand performs marriage according to the Islamic Family Law of Southern Thailand or syarak. That means, they are not supposed to register their marriage under the Civil Law of Thailand. As a result, for any problems that arose after the marriage will be referred to the Islamic Family Law of Southern Thailand. Thus, if the Mosque and Islamic Department are unable to settle those problems, they will be brought to the Civil Court. In brief, the problems still cannot be settled as they did not register their marriage under the Civil Law of Thailand (Mauti. 2009). 
Subsequently, the society in the four districts of the Southern of Thailand should register their marriages under the Civil Law of Thailand even though they performed the marriages according to Islamic Family Law. This is to ensure that any problems arose in future can be settled by using both laws. This issue of unsettled problems does not only concern the problem of hadhanah, but it also concern the issues of inheritance, property of husband and wife and children's maintenance or alimony. The researcher suggests that the authority should pay attention to this matter and improve certain laws to ease the solution for each problem. This is important to ensure that the society will not be the victims of the laws, but enjoying their rights justly. The laws are suggested to be clearer regarding the issue of marriage registration; for instance, it is vital to register a marriage under the Civil Law of Thailand even though that marriage is performed according to the Islamic Family Law of Southern Thailand. Other than that, the laws should also introduce clauses related to marriage and divorce registration and punishment for the lawbreaker in assuring the peaceful practice and solution for family matters.

Besides, the Civil Law of Thailand permits the child to use their father's surname as their last name. If the child was born out of wedlock, he or she is supposed to use the surname from his or her mother's side, in accordance to the provision clause 1561. Meanwhile, the provision clause 1566 and clause 1567 state that parents possess the rights to nurture their children who have not reached their puberty age to ensure that the children grow with love and peace. Thus, if the parents have passed away or disabled, the eligible party should take the responsibility. According to the provision clause 1567, the guardian has the rights to determine the shelter and punishment in educating the children to be good people. If the guardian fails to nurture the children courteously, the child's custody can be reclaimed by others who are eligible.

A case example of the above is case no.
$3780 / 2543$, where the plaintive and defendant got married but they did not register their marriage. Thus, their child from that marriage belongs to the mother, as explained by the provision clause 156 . As a result, that child is under the plaintive (mother) custodian, and the defendant (father) has no right to claim for the custody as he did nor register the marriage or apply for children declaration. Apart from the child's custody belongs to the mother based on the provision clause 1566, the agreement between plaintive and defendant to nurture the children together also cannot be fulfilled, (provision clause 1566(6)). Furthermore, the father has no rights to determine the children's shelter as mentioned in the provision clause $1567(1)$.

On the other hand, if the child is disabled or insane, the appointed guardian by the Court or the eligible guardian holds full responsibility towards that child. That means the Court also has the power to withdraw the rights if more eligible guardian is identified, according to the provision clause 1569 and 1569/1. For instance, in the Court decision no. 1114/2535, it stated that mother is the ultimate guardian in relation to the child's property. Thus, she claimed that the 3 children's property did not belong to her or her ex-husband. As a result, she can use the property for the children's benefit without any permission from the husband.

Moreover, child's custody is not only about nurturing or educating, but it is also about managing the child's property. Therefore, the guardian should manage the child's property honestly and properly, by not causing any harm to them, (provision clause 1571 and 1572). That means the child's money should be used for their life maintenance and education as a priority. If there is balance from the money, it should be given to that child. However, if the guardian does not have money to provide the children's maintenance, he or she should voluntarily give what they have or they can take it from the children's inheritance, as long as they do not violate the use of the property. 
In keeping with the provision clause 157 and 1575, among the matters that should not performed by the guardian towards the children's property are selling or buying, mortgage, and other matters. That means, no changes should be performed on the children's property unless the changes have been approved by the Court for the children's benefits. The guardian is supposed to hand over the power of managing the property once the children reached their puberty and knew how to manage their own property according to the provision clause 1577 , 1578, 1580 and 1581. That example was from the Court decision no. 876/2518, 9414/2542 and $458 / 2547$ from the case of managing children's property by the guardian.

In holding the child's custody, the guardian should declare the property owned by the children in three months after receiving the Court order with the agreement from two witnesses who have reached their puberty or the children's successors. The declaration is important in promising the safety of the property as it should be used for the children's daily expenses, education and other related expenses. Moreover, it will be monitored by the Court to avoid from any faulty acts or violation. In short, the provisions clauses which are preventing the children's property from violation are 1592, 1593, 1594 and 1598/4.

According to the provisions clause 1598/6, the child's custody is over once the children reached their puberty or passed away. That means, when the children passed away; or reached the age of 20 , the custody is over. This is because; being at the age of 20 suggests that the children have sufficient maturity in choosing their way of life and managing their property without any permission from their parents or guardian. Meanwhile the rights of custody for the guardian will be over if any of these things happened; if he or she passed away, or the rights has been withdrawn by the Court; or he or she is declared as disabled; or he or she is declared for bankruptcy; and he or she resigned from the responsibility as agreed by the Court (Ibid,
$1598 / 7,1598 / 8)$

By referring to above clarification, it may be suggested that the Islamic Family Law of Southern Thailand and the Civil Law of Thailand really protect the hadhanah rights towards children. Both laws give priority to the rights of custody, eligibility of the guardians, responsibilities of the guardians, and other rights related to children. In brief, the society especially the parents should be alarmed of their responsibilities towards their children either related to the property or not.

Moreover, children should not be the victim in the conflicts between their parents or guardians. Thus, any problems arising out of the marriage should be referred to the laws. This is because, syarak is determined by Allah and civil law is created by human. In addition, the Islamic Law and the Civil Law pay high attention to the children's welfare, regardless of their status of being the legitimate child or child out of wedlock. Children protection should be widely viewed as it comprises all needs and benefits in terms of physical, mental, spiritual and religion. In brief, this is vital in assuring a safety and peaceful life for the children.

\section{Conclusion}

The discussions suggest that Islam provides a clear and comprehensive guidelines regarding hadhanah. Hadhanah is not merely rights that parents are fighting for, but it is a responsibility that should be clearly understood and accomplished for the sake of children's future. Islamic Law stresses that in the issue of hadhanah, children's welfare and benefits should be the main priority that should be taken into consideration if compared to the benefits for people who are fighting for it. That means, once the decision is made, the guardians should carry the responsibility as perfect as possible. In Southern of Thailand, the Court made decision regarding the issue of hadhanah by referring to the Islamic Family Law which is based on syarak. Other than that, 
the Civil Law of Thailand also protects the issue of hadhanah for children by introducing few clauses in relation to the rights of custody, rights or meeting, maintenance, shelter and other related matters. This is highly significant in protecting the children from the parents' conflicts and hadhanah claim. Besides, the differences in both laws can be accepted as both laws are created based on different references. Even though both laws are different, they are still perfectly protecting the children's rights in hadhanah. In conclusion, both laws are promoting the efforts of assuring the safety and peaceful life for the children despite their parents' conflicts.

\section{References}

Abdul Malek, N. (2007). Hadanah in Islamic Family Law. Vol. 14. Dewan Bahasa dan Pustaka, Kuala Lumpur, Malaysia.

Al-Asiliy, A. M. (2010). al-Furuq al-Fighiyyah baina al-Rajul wa al-Marah. Darul Nafa'is, Urdun

al-Bakhri, M. Z. (2010). Islamic Family System. Selangor, Malaysia, Darul Syakir Enterprise.

al-Dusyuqi, S. D. M. I. (n.d). Hasyiyah alDusuqi 'ala al-Syarh al-Khabir. Vol. 2. Beirut, Dar Ihya al-Kutub al-Rabbiyah,

al-Mubarakfuri, M. A. A. (n.d). Tuhfatul alAhwadhi bi Syarhi Jamik Tarmidhi. Vol. 1. Bab. Maja'a fi Takhyir al-Ghulam bayna Abawaihi Idha Iftaraqa. Bairut, Dar Kutub al-Alamiyah.

al-Nawawi, A. Z. Y. (n.d). Raudhah al-Talibin. Vol. 9. Beirut, Maktab al-Islami.

al-Syatibi. (1997). al-Muwafaqat fi Usul alSyariah. Vol.2. Maktabah Nazar Mustafa alBadh, Saudi Arabia.

al-Syawkani. (n.d). Faihul Qadir. Vol. 3. Beirut Dar al-Kutub al-Alamiyyah.

al-Zuhayli, W. (1985). al-Fiqh al-Islami wa
Adillatuh. Vol. 7. Dimsyiq, Dar al-Fikr.

Annual Report. (2010). Office of Juvenile Justice System Development. Department of Juvenile Observation and Protection, Case Statistics.

Annual Report. (2013). Cast family and heritage demand in the Province of Southern Thailand, Thailand.

Aqlah, M. (1990). Nizam al-Usrah fi al-Islam. Oman, Maktabah al-Risalah al-Hadithah.

Ibrahim, M. R. (2006). Munakahat: Law \& Prosedures. Ampang, Kuala Lumpur, Publiching House.

Islamic Family Law in Brunei (1999), Brunei.

Islamic Family Law in Federal Teritories (1984).

Islamic Family Law in Southern of Thailand (1946), Thailand.

Mohd Zin, N. et.al. (2007). Islamic Family Law. Dawan Bahasa dan Pustaka, Kuala Lumpur, Malaysia.

Muda, Z. (2009). Interaction Social in Islamic Perspective. Selangor, PTS Islamika.

Mulhim, A.S. (1998). Al-Syarh al-Tatbiqiy li Qanun al-Ahwal al-Syakhsiyyah al-Urduniy. Jordan, Maktabah al-Risalah al-Hadithat.

Mustafa al-Khin, M.B. (2009). Al-Figh alManhaji Mazhab al-Syafii. Selangor, Darul Syakir Enterprise.

Qasim, Y. (1992). Huquq al-Usrah. Egypt, Dar Nahdhah al-Arabiyyah.

Sabiq, S. (1967). Figh al-Sunah. Vol. 8. Matbaah al-Tamuzijiyyah, Egypt.

Salleh, H. (1992). Basic of Islamic Family: Discussion of the Four Schools. Dewan Bahasa dan Pustaka, Kuala Lumpur. 